\title{
CONCLUSION OF THE CONTRACT FOR MULTIMODAL TRANSPORT OF GOODS, IN VIEW OF THE NEW LEGISLATION IN KOSOVO
}

\author{
Pregledni rad / Review \\ UDK 656.022.8:341.24 (497.115)
}

\begin{abstract}
This paper will address the general issues concerning the contract of multimodal transport, such as the notion, meaning, terminology, presentation and development, then the elements of the contract, contract forms, and the manner of concluding the contract. The legal definition of multimodal transport contract is given in the United Nations Convention for International Multimodal Transport of Goods, Article 1, and paragraph 3. This convention defines the contract for multimodal transport as follows: "The contract for multimodal transport is a contract whereby the multimodal transport operator undertakes, against payment of freight, to perform or to procure the performance of international multimodal transport. For the realization of multimodal transport activity, the participating parties will clearly define their rights and obligations with the contract that they will conclude, for the multimodal transport of goods. The contract for multimodal transport of goods is a special category regulated by the provisions of the above-mentioned Convention, but in certain cases the provisions of national laws, which regulate legal relations between the operator of multimodal transport (MTO) and third parties that he has engaged in the transport process, are applied. Law on Obligational Relationships as lex generalis does not contain special provisions that regulate the multimodal transport contract, but the provisions of this law, regulating the contracts in general and the freight contracts in particular, apply to this contract.
\end{abstract}

Key words: The United Nations Convention on International Multimodal Transport of Goods, Contracts for Multimodal Transport, Multimodal Transport Operator, the Law on Obligational Relationships.

\section{Introduction}

The technological revolution was undoubtedly an important factor for developments that occurred in all areas in the field of transport. In particular, these changes were expressed

1 Assembly of the Republic of Kosovo 
after the World War II, when the combined transport was at the genesis of its development. The rapid development of science, technology, outlines the necessity for further development of the traffic to the new needs in the national as well as in the international aspect. ${ }^{2}$ In 1966, the first ship container "Fairland" opened the front line of the container in the international aspect and this marked a new form of transport, which began to produce high-level results, by applying technological innovations. ${ }^{3}$ Conventional transport or unimodal transport of goods nowadays is used less and less, although earlier, this mode of transport was the main transportation in the systems of national and international transport. With the introduction and development of modern technologies of transport such as palletization, containerisation, RO-RO, LO-LO, RO-LO, LO-RO, FO-FO, Hucke-pack, and technologies of the bimodal transport, the conventional transportation of goods began to lose its importance, and left its dominant role in the multimodal transport. ${ }^{4}$

In this context, multi-modal transport is increasingly taking place in national and international policies because of the application of new and advanced transportation technologies. In addition, there are numerous advantages in comparison with classical branches of transport, with fast and qualitative services, which will be addressed in this paper; there is also a special priority, which will is named as the ecological advantage due to the fact that it largely preserves the environment. Taking into account the geographical extension of the Republic of Kosovo, railway and road network, construction of the highway Morinë - Merdare, which will be linked to the highway Durrës - Kukës - Morinë, through which not only Kosovo will be linked, but will also link other regional countries with Albanian seaports and with panEuropean corridors. Kosovo should definitely build a new well-developed transportation system, which is very well interconnected with classical transport branches. Therefore, the national policies of traffic and transport, which in the future will be part of the European system should be coordinated and should follow the process of economic development and of the EU traffic, because the integration of the Kosovo state in the EU is conditioned, inter alia, with the establishment of a new traffic and transport system. Thus, the creation and development of multi-modal transport model is a prerequisite for connecting the conveyor system, which will connect the national trends of transport with the EU conveyor (transport) system.

\section{The notion of the multimodal transport contract}

The legal definition of the contract for multi-modal transport is provided in the United Nations Convention on International Multimodal Transport of Goods, under which this contract is defined as follows: "The contract for multi-modal transport is a contract whereby a multi-modal transport operator undertakes, against payment of freight, to perform or to procure the performance of international multi-modal transport." ${ }^{\prime 5}$

\footnotetext{
2 Prof. dr. Mehdi Hetemi, Containerisation of the transport as an integral and composite system, The right, no. 1-4, Pristhina, 2007, page 35.

3 https://www.google.com/\#q=short+histori+of+contenierasation+fairland

${ }^{4}$ Gordana Nikolic, Multi-modal transport, Rjeka, 2000, page 13.

5 United Nations Convention on International Multimodal Transport of Goods, (Geneva, 24 May 1980), article1.3.
} 
In the legal theory, there are authors who rightly think that this legal definition given by the Convention is not complete and does not contain all the essential elements of the legal, economic, technological nature of the multi-modal transport. The definition should be more thorough and comprehensive and should contain the essential elements of the multi-modal transport. $^{6}$

Thus, according to the professor and the eminent Croatian scholar Zelenika, the definition must have a more complete content, according to which: "The work contract of the multi-modal transport is a mutually binding contract, under which the operator of multimodal transport (MTO) is obliged to perform or organize the performance of the works of multi-modal transport and traffic, while the consignor or the payee of the multimodal transport is obliged to pay, to the multimodal transport operator, the specified amount, for the performed service and the reasonable expenses in the process of multimodal transportation".

According to another definition, the contracts for multimodal transport of goods represent such legal work in which the organizer, namely the operator is obliged to organize transportation from the place of departure - set with the help of carriers of at least two branches of transport, with at least two means of transport with a unique document and responsibility, whereas as, the inquirer of the transport is obliged to pay the price of the carrier. ${ }^{8}$

I think that both definitions take into account the specific elements defined by the United Nations Convention on the International Multimodal Transport of Goods, and that a more complete definition will be able to be determined with the involvement of elements provided by both of these definitions, which would be a full involvement of the definitions provided by the convention for multimodal transport contract, which will be elaborated below when treating the essential elements of the contract. ${ }^{9}$

\section{Essential elements of the contract}

In legal theory, many authors have defined the essential elements of the contract for transport as elements of essential importance for the conclusion of the contract. For the conclusion of the contract, parties must express willingness to conclude the contract and agree on the essential elements respectively on the content of the contract. ${ }^{10}$ Essential elements of the contract are therefore those elements, which as such are defined by law, as well as those, which the bidder for the contract - includes them in his bid. ${ }^{11}$

\footnotetext{
${ }^{6}$ Marian Hoeks, Multimodal Transport Law f. 4, published by Kluwer Law International, PO Box 316, Netherlands, Ratko Zelenika, Multimodalni prometni sustavi, page 28/29. Rijeka, 2006.

7 Prof. dr. sc. Ratko Zelenika, Pravo multimodalnoga prometa, Rijeka, 2006, page 135.

8 Mirko Vasiljević, Trgovinsko pravo, SA, Belgrade, 1995, page 533.

9 The work contract of the multi-modal transport is a relatively unique contract and contains elements of the law on economy, trade, shipping, respectively, of the law on multimodal transport, and the rules and provisions of the United Nations Convention on international multi-modal transport of goods, apply to these contracts. Also to an extent the provisions of national legislation, of the national and international legal acts which regulate the relations between the multimodal transport operator (MTO) and the third parties, whom he has engaged in the process of multimodal transportation, apply to these contracts.

10 Prof. dr. sc. Ladislav Horvat, Cestovno prometno pravo, Zagreb, 2002, fq.137; Branko Jaksa, Kopneno i zraćno saobraćajno pravo, Zagreb, 1969, fq. 183; Prof. dr. sc. Ladislav Horvat, Mr. sc. Slobodan Kaštela, Osnove zraćnog prava, Zagreb, 1998, page 81.

11 Prof. dr. Sc. Ladislav Horvat, Cestovno prometno pravo, Zagreb, 2002, page137.
} 
Essential elements of the multi-modal transport contract imply those elements that are of essential importance for the validity of the contract, without the existence of which the contract cannot be considered as concluded with certain legal effects to the contracting parties, and without which the activity of multi-modal transport cannot be organized and become operational, and a special attention shall always be paid to the existence of these elements.

Whenever it comes to multi-modal transport contract, attention should be given to the elements of the contract, such as: the subject of the contract, the price of multi-modal transport service, other essential elements that are of great importance, and other non-essential elements. $^{12}$

Even the Law on Obligational Relations contains the provision, which stipulates that the contract is concluded when the contracting parties have agreed on the essential elements of the contract. ${ }^{13}$

Below we will briefly address the essential elements, which the contract for multi-modal transport must contain.

\section{Subject of the contract}

The subject of the contract is a general condition for signing (concluding) the contract. The subject of the contract presents the elements for which the parties have agreed, or "for what the contract is concluded". ${ }^{14}$ The definition given by the legal theory of the subject of the contract applies to the transportation contract in general, and to the multi-modal transport in particular. Subject and the price for transport are essential elements in the transportation contract. ${ }^{15}$

The subject of the contract, without a doubt, is one of the most important elements of the contract for multi-modal transport, which contains the actions and activities that will be organized or undertaken by the multi-modal transport and multi-modal traffic operator, in the process of multi-modal transport and traffic in order to fulfil the contract.

In order to consider that this element is fulfilled, it is irrelevant whether the subject of the transportation contract and of the multi-modal movement consists of one or more activities, namely undertakings or actions taken by relevant subject, i.e. the multi-modal transport operator (MTO) and the third parties, who have been engaged by the operator in the multimodal transport process.

Thus, the multi-modal transport contract includes all activities of the multi-modal transport, and not only the transport, without which it would not be possible to organize and operationalize the certain multi-modal transport.

Such activity must be safe, rapid, and rational, this means that it must satisfy the ecological aspect to which increasingly is being given special importance in all economic activities, manufacturing and transporting, by regulating this matter with national laws and EU legislation.

\footnotetext{
12 Prof. dr. sc. Ratko Zelenika, Pravo multimodalnoga prometa, Rijeka, 2006, page 136.

13 Law on Obligational Relationships, Law no. 04/L-077, article 15.

14 Prof. dr. Nerxhivane Dauti, Contracts (for MA studies), Prishtina, 2012, page 36.

15 Prof. dr. sc. Ladislav Horvat, Cestovno prometno pravo, Zagreb, 2002, page 137.
} 
Viewed from a practical aspect, one can rightly say that the contracts for multi-modal transport concluded between the contracting parties, for the international transportation of goods, does not indicate which activities should be undertaken by the operator, but always emphasizes the obligation of the operator to do or organize the transport of the delivery set under certain conditions. ${ }^{16}$

\section{Multimodal transport price}

Transport price is one of the essential elements of the transport (freight) contracts, regardless of the branch of transport. National and international legislation have regulated the essential elements of the transport (freight) contracts in general. Numerous authors in the field of transport point out transport price as one of the essential elements of the transport contract, it is considered as an important element of the transport contracts in all branches of transport, with conditions and modalities for the respective areas. Even the law on obligational relationships contains the provision that foresees the duty to pay the price of transport.

"Unless stipulated otherwise in the contract of carriage or the bill of freight, the recipient shall, upon accepting the consignment and any bill of freight undertake to pay the carrier for transport and the sums charged on the consignment ${ }^{\prime 17}$

Therefore, given what was said above, one could conclude that the price of transport is an element of great importance to transport contracts, including multimodal transport.

This conclusion comes automatically if one takes into account international law, namely the United Nations Convention on International Multimodal Transport of Goods, given the wording of the Convention; it appears that this issue is an essential element of the contract. ${ }^{18}$

In the theory of the multi-modal transport, there are also theorists who consider that despite the importance of the multi-modal transport price, nevertheless, it cannot be considered as an essential leading element of the multi-modal transport contract, but as one of the essential elements. ${ }^{19}$

16 Prof. dr. sc. Ratko Zelenika, Pravo multimodalnoga prometa, Rijeka, 2006.

17 Law on Obligational Relationships, Law no. 04/L-007, article 684.

18 United Nations Convention on International Multimodal Transport of Goods, (Geneva, 24 May 1980), article 2. 3.

19 Prof. dr. sc. Ratko Zelenika, Pravo multimodalnoga prometa, Rijeka, 2006, fq. 138-139. According to the approach represented in theory by Zelenika, the multimodal transport price is only one of the important elements in addition to other elements of creation, design and operationalization of transport activity or multimodal traffic. Thus, these activities and enterprise of multimodal transport entities include, not only the transportation of the shipment, the use of at least two modes of transport, but also include all operations, meaning the price of those activities of composite transport, the activities of multiple and diverse transport according to the principle "from door to door", "from producer to consumer", "from the seller to the buyer or consumer". In addition to these elements, the contract of multimodal transport has other important elements such as quantity, weight and type of packaging of goods, the name of the product in the respective language of the world and in the national language of the operator and the consignor, and the code and name of the product that is imported or exported, according to the customs tariff, the value of goods in the national currency of the operator or the consignor and the relevant foreign currency, delivery conditions under which clauses will be done the delivery, such as CIF, FOB, Inco-terms 2000, the terms of payment, who pays the transport price, consignor or recipient, road transport, transport means, the time of delivery to the place of delivery as is stipulated in the contract between the operator and the user of the transport, reception quality and quantity of goods, provision of transport, carrying out customs procedures, payment of the customs duties and taxes, the state of delivery, the port of unloading, or the 
When setting the price of the multimodal transport, the multimodal transport operator should be careful, and should calculate the cost of the actions that are necessary for the fulfilment of the contract, in order not to have later on further requests for additional payment, which will be realized with difficulties and only after assessing the reasonableness of the undertaken actions which have caused additional costs.

Regardless the branch of the transport in question, the transport price contracts of the transport contracts, according to the authors, represents the amount of money, which must be paid to carriers for the service, i.e. the completed transport. When determining the price of the contract, the contracting parties, each time, must take into account the transport fees for the respective branches. ${ }^{20}$

Carrier (transport) price in the multimodal transport contract shall be fixed so that in principle the contracting parties, when entering into the contract and when determining the price of transport, take into account certain fees set for the transport, and should consider local customs of the multimodal transport operator and it is in the interest of the multimodal transport operator to be careful, especially when setting the fees, so that these fees are more reasonable and more attractive to the users of the multimodal transport.

In this regard, today there are several types of fees set by multimodal transport operators, which are represented by the multimodal transport operators to the users as well as to those who in the future may be potential users ${ }^{21}$

\section{Non-essential elements}

Besides the essential elements, the contract for transport, as well as other contracts, may also contain other non-essential elements. ${ }^{22}$

Even contracts for multimodal transport, in addition to the essential elements of the multimodal transport contract, also include other elements, which are not essential, but still are important, and cannot be called trivial.

These elements are classified, respectively, are regarded as non-essential elements because even if there is a lack of these elements in the multimodal transport contracts, do

port of destination, storage, railway station for unloading, address and the name of the shipper, the consignee and the name and residence address of the multimodal transport operator, the statement that the transportation is subject to the relevant rules of the UN Convention on international multimodal transport of goods, the appointment of a competent court or arbitration in case of dispute.

20 Branko Jaksa, Kopneno i zraćno saobraćajno pravo, Zagreb, 1969, fq. 457-481; Mirko Vasiljević, Trgovinsko pravo, SA, Beograd, 1995, fq. 615; Prof. dr. Slavko Carič, prof. dr. Ivica Jankovec, Prof. dr. Predrag Šulejič, prof. dr. Miodrag Trajkovič, Saobračajno pravo, Novi Sad, 1998, fq. 146 dhe faqe 265.

${ }^{21}$ It will be in the interest of the current or for the future users to mention or present three types of fees that these multimodal transport users will be able to encounter :

- Potential fees - linear, are those tariffs under which, for the performance of transport services, operators calculate equal fees, regardless of the volume of services that offer multimodal transport operators.

- Digressive fees imply those fees which are intended to stimulate the demand of the users of transport services, provide that if the volume of the requests of the transport users increases, it will come to the reduction of prices of those services proportionally with a volume increase of demand

- Preferential tariffs are those tariffs which provide substantial relief to the user of the services of the operator under certain conditions (Prof. dr. sc. Ratko Zelenika, Pravo multimodalnoga prometa, Rijeka, 2006, fq. 138).

22 Prof. dr. sc. Ladislav Horvat, Cestovno prometno pravo, Zagreb, 2002, fq. 137. 
not invalidate the contract, because these elements do not have any impact, or effect on the existence of the multimodal transport contract.

In this group of elements belong, as, for example, the number and date of the contract, telephone and fax numbers of the contracting parties, records of issuance of the guarantees etc. $^{23}$

\section{Conclusion of the multimodal transport contract}

When talking about the connection of the multimodal transport contract, we can say that this contract has shared rules that apply to certain contracts usually associated with the economic circulation.

In some areas of transport, such as rail transport, legal provisions provide the obligation for concluding the transport contract.

Next, we will discuss the manner of concluding the contract for transportation, since these contract' rules are also expressed on the occasion of the conclusion of the multimodal transport contracts where the contracting parties take over the rights and obligations specified in this contract.

Contract agreement on multimodal transport can be made between parties who are not present in the same place and location.

Our law contains general rules and in such cases considers that deals with distance contracts.

The distance contracts for the delivery of goods or provision of services, which are agreed between entrepreneurs and consumers, by using exclusively means of communication at a distance, unless the bond contract is not within the distribution system or the system of services organized for remote works.

According to the Law on Obligational Relationships, the means of distance communication are communication tools that can be used for preparation or for the conclusion of the contract between the consumer and the entrepreneur without the simultaneous physical presence of the contracting parties, especially letters, catalogues, phone, fax, electronic mail (e-mail), and radio media services and telecommunication.

"An offer given to a person in absentia in which a deadline for acceptance is not stipulated shall be binding for the bidder for the time usually required for the offer to reach such person so it may be studied and decided upon, and for the response to reach the bidder." ${ }^{24}$

Contracting Parties or multimodal transport operator (MTO) and the shipper may conclude this contract in the following manners:

a) Entering into a contract over the phone

Conclusion of the contract today by phone is more prevalent in business practice, and this issue treated in the legal literature. ${ }^{25}$

\footnotetext{
23 Prof. dr. sc. Ratko Zelenika, Pravo multimodalnoga prometa, Rijeka, 2006, fq. 140.

24 Law on Obligational Relationships, Law no. 04/L-007, article 26.3.

25 Prof. dr. Mehdi J. Hetemi, Some current topics of market economy, Prishtine, 2005, page 393.
} 
Entering into the contract for multimodal transport over the phone is a recognized practice not only by legal theory, but also by the business practices, by adopting general rules for the conclusion of contracts between the non-present parties, and the offer, of one contracting party made to the other party over the phone, is deemed valid.

Entering into a contract over the phone is recognized by our practice and legislation, so the Law on Obligational Relationships has provided:

"The offer, which is made by phone or directly through a radio connection or through direct communication, shall be considered to be an offer to the present person."26

In legal theory, there are opinions that contract, which is concluded over the phone, will be considered as valid under certain conditions, aiming to increase the legal certainty, due to the fact that the risk to suffer damage is every time present for the contracting parties.

Thus, by analysing the former Law on Obligational Relationships (LOR), Professor Mehdi Hetemi rightly concluded that:

"LOR (of the year 1978) did not have the general rules no. 30 of business law, which contains the rules that the parties should verify the contents of their statements by exchanging registered letters no later than the next working day after the declaration has been issued".27

In order to increase the legal certainty and to reduce risk, it would be good to require the bidder to confirm its bid given by the phone to the other party. The confirmation of the bid, in such cases, should be done each time through a registered letter or forms, or through other electronic communication, which should be sent no later than the next day, given the level of the development of information technology these days, because the provisions of the Law on Obligational Relationships provides such possibility by determining that:

"The business customs, usages, and practice established between parties shall be taken into consideration in the assessment of the behaviour required and effects thereof in the obligational relationships of commercial entities".28

Lack of this letter does not therefore invalidate the contract concluded by telephone, but the party, which did not give the written confirmation to the other party, is not responsible for the caused damage. ${ }^{29}$

The practice is such because it is difficult to really know if the offer came from an authorized party, or if the offer has been given to another authorized party, namely to know whether we are dealing with a real and serious offer.

An issue that also exacerbates the position of economic entities, which by their activities appear as a contracting party, are also issues relating to the question of who will bear the consequences in the event that the telephone conversation, for the multimodal transport contract, has created confusion as a result of outages and interruptions of the telephone line, and how to prove that the contract is concluded over the phone. ${ }^{30}$

\footnotetext{
26 Law on Obligational Relationships, Law no. 04-L-077, article 26.5.

27 Prof. dr. Mehdi J. Hetemi, Some current topics of market economy, Prishtine, 2005, page 396.

28 Law on Obligational Relationships, Law no. 04-L-077, article 11.

29 Prof. dr. sc. Ratko Zelenika, Pravo multimodalnoga prometa, Rijeka, 2006, fq. 146.

30 Prof. dr. Mehdi J. Hetemi, Some current topics of market economy, Prishtine, 2005, page 393-396.
} 
The rapid technical and technological development that characterizes recent years, the subjects exercising economic activities were forced to apply these achievements in their economic activities, despite the risk and uncertainty in certain moments that may occur with the application of these achievements.

The dynamics of development did not bear rigid rules and the usefulness that business entities had from the application of the latest technical technological achievements was greater than the risk of damage.

Some authors ${ }^{31}$ analysed the benefits, advantages, risks and necessity of the application of these forms of the business development, by concluding rightly, that subjects who conduct economic activities in the circulation of goods and provision of services enjoyed the security offered by these circumstances, believing in legal fictions behind the bid, i.e. believing that on the other side of the telephone stood the authorized party and that actually wanted the contract for multimodal transport.

Thus, according to them, this problem is diminished by the fact that in business practice, the parties, which conclude contracts for multimodal transport, are mainly familiar with each other, by the previous activity, and they can have appropriate information by being careful.

Nowadays, thanks to technical-technological development, the information related to the particular economic subject is easy to be obtained, due to the fact that the multimodal transport operators (MTO) are exclusively those entities that in accordance with the provisions of national law are registered in the competent bodies. ${ }^{32}$

b) Conclusion of the Contract through telegram

The conclusion of the contract for multimodal transport through the telegram is a way that perhaps belongs more to the past than the present, due to the fact that recent technological developments have highlighted the new opportunities and developed new ways of making the arrangements for circulation of goods and provision of services in the economy in general, which are reflected in the multimodal transport contracts. ${ }^{33}$

In addition, in this case, sometimes situations arise, which express perhaps a dose of uncertainty to the contracting parties, taking into account the technical aspects of concluding the contract through a telegram.

The most disputable issues in the national theory and legislation and in international law remain issues of technical implementation of the conclusion of the contract, because the telegram does not contain the signature of the consignor, since the consignor does not write the telegram by himself, and in this regard even the text of the telegram content is not written by the consignor, and the possibility, of errors or ambiguities during the conclusion of the contract, is present.

Regarding the national legislation of different countries and that of Kosovo, in the event of concluding the contract through the telegram, it is considered that the contract is concluded between the parties who are not present. In order to avoid these risks or avoid situa-

\footnotetext{
31 Prof. dr. Mehdi J. Hetemi, Some current topics of market economy, Prishtine, 2005, page 393-396. Prof. dr. sc. Ratko Zelenika, Pravo multimodalnoga prometa, Rijeka, 2006, fq. 146-147.

32 Prof. dr. sc. Ratko Zelenika, Pravo multimodalnoga prometa, Rijeka, 2006, Pq. 146.

33 Law on Obligational Relationships, Law no. 04-L-077, article 26.5.
} 
tions, creating insecurities and uncertainties, which would consequently damage the other contracting party, a registered letter should confirm every contract that is concluded through telegram.

c) Conclusion of the contract through fax

The conclusion of the multimodal transport contract through fax is present even nowadays, taking into account the fact that in comparison with the two ways mentioned above, on the occasion of the conclusion of the contract in terms of technical specifications has evident precedence compared with the other two above mentioned manners of concluding contracts for multimodal transport.

So, the conclusion of the contract by fax in general will always be easier and safer for contracting parties than signing the contract with telephone and telegram, due to the fact that now the contact between the contracting parties is more close and direct, and therefore the possibility of errors and uncertainties is smaller.

In the case when the contract, on multimodal transport, is concluded over the fax, the contracting parties have the opportunity to clearly express terms of the contract and thus the uncertainty of the contracting parties is minimized, if not avoided entirely.

Despite these strengths and advantages that this manner of concluding contracts on multimodal transport has in comparison with the two above-mentioned manners, yet the national legislation of different countries, and the legislation in Kosovo, when this manner of concluding the contract is applied, considers that contract has been concluded between non-present parties.

d) Conclusion of the contract on multimodal transport through electronic form

The rapid technical-technological developments, and in particular that of information technology, which is characterized by a widespread computer network distribution and the growing use of the Internet, are new foundations on which the new system is built, and in which the economic development of the states is strongly leaning on.

This development led to an increase of the competition in the international market because of the speed of receiving and sending the necessary information for entities conducting economic activities in major international distances, therefore electronic commerce appeared as innovation.

Electronic Commerce represents the business information exchange, the business relations development, conducting business transactions through the network of telecommunication.

Thus, the conclusion of the contract for multimodal transport through electronic means is the result of the information technology developments in recent years that are expressed through the internet network and other systems of online connections, and also as a result of electronic data interchange (date Interchange - EDI, UN-EDIFACT EDI for Administration, Commerce and Transport). ${ }^{34}$

34 Tanja Poletan Jugović, Ph. Dr. Ana Perić Hadžić, Mr. sc., Dario Ogrizović, B.sc., Importance and effects of the electronic documents implementation in the service of logistics - forvarder operator, Pomorstvo, god. 23 (2009), Pomorski Fakultet u Rijeci, fq. 221-242. 
The conclusion of the contracts, for the circulation of goods and provision of services, acquisition, transport in general, and for the multimodal transport, through electronic means is dominant and characterizes the business of this century, given primarily the technical advantages and security that creates, in economic relations, the application of these achievements compared with the three above mentioned manners. ${ }^{35}$

Despite these mentioned advantages, even this manner of concluding contract presents difficulties for the fact that this is something new, and when we consider the fact that nowadays in some countries, the conclusion of the contract through internet, is not sufficiently regulated by law, the issue gets somehow complicated.

The particular problem arises when concluding the multimodal transport contract with electronic signature, although national legislation of different countries regulates the issue of electronic signature, by special laws.

The LMO of Kosovo contains the rules under which it is envisaged that if the law does not explicitly states otherwise, the written form is replaced with statements by electronic means, to which apply the provisions of a special law. ${ }^{36}$

e) Conclusion of the contract through the authorized person

Conclusion of the multimodal transport contract, through authorized person - the representative, is less expressed in business practice, but it is present and can be referred to as a manner for concluding the multimodal transport contract.

In this case, it should be noted that the authorized person can enter into a contract only within the limits of the given authorization, and authorization of a certain form is needed for the assigned job.

The authorized person may only take legal action for which is authorized.

Authorizer may, upon its own will, reduce or revoke the given authorization, even if with the contract has expressively waived from such possibility, if the compensation for the damage suffered in this case, is given to the authorized person.

Transgression of authorization by the authorized person for the works of multimodal transport mainly appears in two forms:

Material transgression which is expressed in those cases where the authorized person exceeds the limits that are set in the text of the authorization, referring to the letter with which the authorized person has admitted to carry out certain works, and secondly, the transgression can be in terms of time, where the authorized person works under the expired authorization.

Therefore, as in both these cases, it is important to ascertain that the other party knew or should have known that the authorized person has passed over the limits of authorization, or that the validation of authorization has ended, meaning that the validity of the contract depends on the honesty of the other party.

\footnotetext{
35 Dr. sc. Čedomir Dundović, Dr. sc.Tanja Poletan, Mr. sc. Ines Kolanović, Implementacija informacijsko komunikacijskih tehnologija u lukama, pomorstvo, god.19(2005), Pomorski Fakultet u Rijeci, fq. 99-115.

36 Law on Obligational Relationships, Law no. 04-L-077, article 26.5.
} 
Law on Obligational Relationships of Kosovo provides the possibility of concluding a contract through the representative, meaning that Contracts and other legal transactions may be concluded via a representative. The entitlement to representation shall be based on the law, on other legal acts and on the declaration of intention by the person represented (authorization). ${ }^{37}$

\section{f) Conclusion of the multidimensional transport contract with adhesion}

The provisions of the contract that is concluded with adhesion are characterised by the fact that one party has substantially more economic power than the other one. One party dictates and imposes its own terms to the other party, which is subjected economically. This means that the provisions of such unilateral contract are prepared by the stronger party and are exclusively based on his personal interest. The provisions of these contracts are fixed, which means that the other contracting party which is in an unfavourable economic position so has the opportunity only to choose whether he/she will accept or refuse the terms of the contract.

These contracts in practice are present today in the works of multimodal transport.

In legal theory are known three types of these contracts, which are allocated based on the criteria of eligibility of avoiding the contract terms. We have complete adhesion contracts, typical adhesion contracts and general conditions of business as adhesion contracts. Bellow, we will briefly explain the meaning of these three contracts.

Contracts of complete adhesion are those contracts, which are concluded when the offeree accepts all conditions of the contract "en bloc", which means that the bidder does not allow any modification of the provisions of the contract set in advance while the offeree fully may accept or reject the terms of this contract. Therefore, as is seen in this contract, the offeree is unable to selectively accept or modify the conditions of the contract contained in the provisions of this contract. In this case, the position of the offeree is disadvantageous because the contract terms are imposed on him.

Typical adhesion contracts are those contracts, which are a bit more flexible. In this type of contract, the bidder prepares the draft contract, but allows negotiations, thus allowing even to make changes in the terms of this contract, which is drafted beforehand.

General business conditions as adhesion contract. This form is expressed by the fact that often in business practice, the business conditions represent only a fraction of the provisions of the contracts, which the parties incorporate (include) in their contracts, either by invoking them in whole or in part. This involvement is supposed in the case when at the time of conclusion of the contract; the offeree is familiar with the conditions of the bidder.

This actually means that the call to the general conditions may be in silence, for example, the Contracting Parties have concluded several contracts with the same general conditions, and although in the following, the contract the general conditions are not mentioned decisively, this means that this contract is based on the general conditions known to the offeree.

This type of contract is concluded without prior negotiations on the essential elements of the contract and the transport multimodal operators offer the contract to the shippers of

37 Law on Obligational Relationships, Law no. 04-L-077, article 72. 
goods, since the contract in question is prepared in writing beforehand. After the conclusion of the contract, MTO issues a stereotyped document to shippers, as evidence for the conclusion of the contract.

g) Conclusion of the multimodal transport contract through silence

The conclusion of the multimodal transport contract through silence implies a situation in which the parties have not said a word, and that nothing is written, meaning that in this case we have a passive attitude of the offeree.

In this case, we are literally dealing with the silence, which in principle does not mean that the offer is accepted by the offeree. The business practices and the judiciary in certain cases, consider that silence is consent.

So when the offeree is in ongoing business relationship with the bidder regarding certain goods, it shall be deemed to have accepted the offer that has to do with such merchandise if the offer is not rejected immediately or within the given deadline.

Whether the silence will be considered as an admission or not that does not depend on the willingness of the bidder but depends on exceptional circumstances. The bidder cannot determine that the silence of the offeree means acceptance, but can agree with the offeree to consider his silence as acceptance.

Law on Obligational Relationships regulates this situation, and the silence of the offeree does not mean acceptance of the offer. In this law, it is clearly stated that:

"Any provision in an offer whereby the silence of the addressee or any other omission thereby (e.g. if the addressee fails to reject the offer in the period stipulated or if the sent material for which the offer was made is not returned in the time specified) will apply as acceptance of the offer shall be without effect.

However if in respect of specific goods the addressee is in a constant commercial link with the offeror an offer relating to such goods shall be deemed to have been accepted if it is not rejected immediately or within the period stipulated".38

\section{Conclusion}

As a result of the development of modern technologies of transport RO-RO, LO-LO, RO-LO, LO-RO, FO-FO, Huckpack and of the bi-modal technologies, the multimodal transport becomes more important and also marks an increase of efficiency in the transport of goods, reducing, at the same time, the negative impacts on human health, in environment and nature.

Applications of modern transport technologies mentioned above, however, have a special role and importance of economic development and with their application in the transport system in Kosovo Republic, which will help Kosovo to join the European carrier system, more quickly and easily.

International multimodal transport of goods, due to its importance and complexity in the national and international economic systems, is known as a composed system, which pro-

${ }^{38}$ Law on Obligational Relationships, Law no. 04-L-077, article $30.2 ; 30.3$. 
vides a range of transport activities of the direct or indirect participants, who make it possible the transportation of goods from one country to another one. The multimodal transport operator enables the goods to be transported quickly and safely.

Therefore, the national policies of traffic and transport, which in the future will be part of the European system, should be coordinated and should accompany the process of economic development and that of the EU traffic, because the integration of the Kosovo in EU is conditioned, inter alia, with the creation of a new traffic and transport system. Thus, the creation and development of the multimodal transport model are prerequisites for connection of the transport system, which will connect the national trends of transport with the European transport system.

\section{B I B LIOGRAPHY}

1. Branko Jaksa, Kopneno i zraćno saobraćajno pravo, Zagreb, 1969;

2. Dr. sc. Čedomir Dundović, Dr. sc.Tanja Poletan, Mr. sc. Ines Kolanović, Implementacija informacijsko komunikacijskih tehnologija u lukama, pomorstvo, god.19(2005), Pomorski Fakultet u Rijeci;

3. https://www.google.com/\#q=short+histori+of+contenierasation+fairland

4. Gordana Nikolic, Multi-modal transport, Rjeka, 2000;

5. Prof. dr. sc. Ladislav Horvat, Cestovno prometno pravo, Zagreb, 2002;

6. Prof. dr. sc. Ladislav Horvat, Mr. sc. Slobodan Kaštela, Osnove zraćnog prava, Zagreb, 1998, p;

7. Law on Obligational Relationships, Law no. 04-L-077

8. Marian Hoeks, Multimodal Transport Law f. 4, published by Kluwer Law International, PO Box 316, Netherland;

9. Prof. dr. Mehdi Hetemi, Containerisation of the transport as an integral and composite system, The right, no. 1-4, Pristhina, 2007;

10. Prof. dr. Mehdi J. Hetemi, Some current topics of market economy, Prishtine, 2005;

11. Mirko Vasiljevi, Trgovinsko pravo, SA, Belgrade, 1995;

12. Prof. dr. Nerxhivane Dauti, Contracts (for MA studies), Prishtina, 2012;

13. Prof. dr. sc. Ratko Zelenika, Multimodalni prometni sustavi, Rijeka, 2006;

14. Prof. dr. sc. Ratko Zelenika, Pravo multimodalnoga prometa, Rijeka, 2006;

15. Prof. dr. Slavko Carič, prof. dr. Ivica Jankovec, Prof. dr. Predrag Šulejič, prof. dr. Miodrag Trajkovič, Saobračajno pravo, Novi Sad, 1998;

16. Tanja Poletan Jugović, Ph. Dr. Ana Perić Hadžić, Mr. sc., Dario Ogrizović, B.sc., Importance and effects of the electronic documents implementation in the service of logistics - forvarder operator, Pomorstvo, god. 23 (2009), Pomorski Fakultet u Rijeci;

17. United Nations Convention on International Multimodal Transport of Goods, (Geneva, 24 May 1980) 


\section{Sažetak \\ SKLAPANJE UGOVORA ZA MULTIMODALNI PRIJEVOZ U SVIJETLU NOVE LEGISLATIVE NA KOSOVU}

Ovaj rad će se osvrnuti na opća pitanja koja se odnose na ugovor multimodalnog prijevoza kao što su pojam, značenje, terminologija, prezentacija i razvoj, elementi ugovora, ugovornih formi i načina zaključivanja ugovora. Pravna definicija ugovora multimodalnog prijevoza je donesena Konvencijom UN-a za međunarodni multimodalni prijevoz roba, članak 1, stavak 3. Ova konvencija definira ugovor za multimodalni prijevoz kako slijedi: “Ugovor za multimodalni prijevoz je ugovor po kojem multimodalni prijevoznik se obvezuje, uz plaćanje terete, da će izvesti ili omogućiti izvođenje multimodalnog međunardonog prijevoza. Stranke koje sudjeluju će definirati vlastita prava l obveze ugovorom koji će zaključiti za multimodalni prijevoz roba u svrhu ostvarivanja multimodalne prijevozničke aktivnosti. Ugovor za multimodalni prijevoz roba je posebna kategorija regulirana mjerama spomenute Konvencije, ali u iznimnim slučajevima se primjenjuju mjere državnih zakona koji reguliraju pravne odnose između operatera multimodalnog prijevoza (MTO)i trećih stranaka angažiranih u prijevozničkom procesu. Zakon o obveznim odnosima ne sadrži posebne mjere koje reguliraju ugovore multimodalnog prijevoza, ali se primjenjuju mjere ovog zakona koje reguliraju ugovore općenito i ugovore o teretu.

Ključne riječi: Konvencija UN-a za međunarodni multimodalni prijevoz roba, ugovori za multimodalni prijevoz, operater multimodalnog prijevoza, Zakon o obveznim odnosima. 
